\title{
Biofuel Expansion, Fertilizer Use, and GHG Emissions: Unintended Consequences of Mitigation Policies
}

\author{
Amani Elobeid, ${ }^{1}$ Miguel Carriquiry, ${ }^{1}$ Jerome Dumortier, ${ }^{2}$ Francisco Rosas, ${ }^{3}$ Kranti Mulik, \\ Jacinto F. Fabiosa, ${ }^{5}$ Dermot J. Hayes, ${ }^{6}$ and Bruce A. Babcock ${ }^{6}$ \\ ${ }^{1}$ Center for Agricultural and Rural Development, Iowa State University, 260 Heady Hall, Ames, IA 50011-1070, USA \\ ${ }^{2}$ School of Public and Environmental Affairs, Indiana University-Purdue University Indianapolis, BS 4074, 801 W. Michigan Street, \\ Indianapolis, IN 46202, USA \\ ${ }^{3}$ Universidad ORT Uruguay and Centro de Investigaciones Económicas, Boulevard España 2633, 11300 Montevideo, Uruguay \\ ${ }^{4}$ Union of Concerned Scientists, 1825 K Street NW, Suite 800, Washington, DC 20006-1232, USA \\ ${ }^{5}$ U.S. Agency for International Development, 1300 Pennsylvania Avenue NW, Washington, DC 20523, USA \\ ${ }^{6}$ Department of Economics, Iowa State University, 260 Heady Hall, Ames, IA 50011-1070, USA
}

Correspondence should be addressed to Amani Elobeid; amani@iastate.edu

Received 7 March 2013; Accepted 29 September 2013

Academic Editor: Silvia Secchi

Copyright (C) 2013 Amani Elobeid et al. This is an open access article distributed under the Creative Commons Attribution License, which permits unrestricted use, distribution, and reproduction in any medium, provided the original work is properly cited.

\begin{abstract}
Increased biofuel production has been associated with direct and indirect land-use change, changes in land management practices, and increased application of fertilizers and pesticides. This has resulted in negative environmental consequences in terms of increased carbon emissions, water quality, pollution, and sediment loads, which may offset the pursued environmental benefits of biofuels. This study analyzes two distinct policies aimed at mitigating the negative environmental impacts of increased agricultural production due to biofuel expansion. The first scenario is a fertilizer tax, which results in an increase in the US nitrogen fertilizer price, and the second is a policy-driven reversion of US cropland into forestland (afforestation). Results show that taxing fertilizer reduces US production of nitrogen-intensive crops, but this is partially offset by higher fertilizer use in other countries responding to higher crop prices. In the afforestation scenario, crop production shifts from high-yielding land in the United States to low-yielding land in the rest of the world. Important policy implications are that domestic policy changes implemented by a large producer like the United States can have fairly significant impacts on the aggregate world commodity markets. Also, the law of unintended consequences results in an inadvertent increase in global greenhouse gas emissions.
\end{abstract}

\section{Introduction}

World agriculture has been significantly impacted by a number of events that have occurred in the past five to ten years. Arguably the most prominent is the dramatic global expansion of biofuels, especially in the United States and Brazil, driven by mandates, federal and state incentives, and trade barriers [1]. Energy prices have also increased to record levels, with the world crude oil price exceeding \$130 per barrel in July of 2008 and currently hovering between $\$ 101$ and $\$ 105$ per barrel. ${ }^{1}$ These higher energy prices have a significant impact on biofuel expansion (Hayes et al., 2009) as biofuels became economically attractive even without subsidies [2]. Additionally, several major policy initiatives relating to climate change in general and biofuels in particular were initiated in a number of countries. These include such policies as the American Clean Energy and Security Act of 2009 (ACES) (H.R.2454) and the Energy Independence and Security Act of 2007 (EISA) in the United States (Public Law 110-140) and the 2009 Energy and Climate Change Package in the European Union [3, 4], which have also contributed to increases in ethanol and biodiesel production. ${ }^{2}$

While biofuel production has been touted as a solution to the adverse environmental impacts of fossil fuels, studies have challenged this notion especially as it relates to indirect land-use change [5-8]. Biofuel expansion leads to increased 
production of agricultural feedstock for biofuels and can lead to indirect land-use change as the increased production of crops used for biofuels displaces existing production of other crops. This can result in an expansion of cropland to replace displaced crops and the unintended consequence of releasing more carbon emissions as land with high natural carbon stocks is brought into production. Thus, climate change policy initiatives are supported by economic analyses pointing to land-use change as a major contributor in greenhouse gas (GHG) emissions impacts. The California Air Resources Board [9] estimates GHG emissions from land-use change to account for $29 \%$ to $69 \%$ of total emissions. The U.S. Environmental Protection Agency's Renewable Fuel Standard (RFS2) life-cycle analysis includes other sources of GHG emissions such as emissions from livestock production, use of farm inputs such as fertilizer, and methane from rice, but GHG emissions from land-use change still account for $35 \%$ of total emissions.

Agricultural management practices in general and land use in particular play a key role in determining the effectiveness of major policy proposals aimed at mitigating climate change, including the implementation of different offset policies that encourage afforestation. A report by the USDA [3] shows that a carbon price of $\$ 34$ would lead to 34.5 million acres of new forest resulting in a decline of cropland and pasture by 21 and 13.3 million acres, respectively. Using a significant amount of US cropland to grow trees would cause an increase in agricultural commodity prices in the United States and consequently impact agriculture in other countries.

Additionally, the increased application of fertilizers and pesticides as well as changes in land management practices (e.g., corn-corn rotation versus corn-soybean rotation) associated with higher biofuel production has been shown to have environmental consequences in terms of water quality, pollution, and sediment loads [10]. Revell et al. [11] also found that increased biofuel production leads to large nitrous oxide $\left(\mathrm{N}_{2} \mathrm{O}\right)$ emissions from nitrogen-based fertilizer use, which could be damaging to the ozone layer.

Given the increased use of both agricultural land and fertilizer brought about by biofuel expansion and the corresponding environmental effects, the overall purpose of this study is to provide policy-relevant information to further the development of rational policies aimed at mitigating negative environmental impacts of the expanded production in the agricultural sector. Specifically, the objective is to analyze the impact of two alternative policy scenarios. The first is a US fertilizer tax scenario, where a tax on nitrogen fertilizer increases its price by $10 \%$. The second is a policy-driven afforestation scenario, in which we evaluate the effects of large areas of cropland being used for forests to sequester carbon, in response, for example, to incentive payments for carbon.

An improved version of the deterministic FAPRI-CARD agricultural modeling system is used for this analysis. ${ }^{3}$ First a baseline is established and then the two scenarios are run. The impacts of these scenarios on the production, trade, prices of agricultural commodities, and GHG emissions both in the United States and globally are measured in terms of their resulting difference from the baseline. The paper is organized into five sections. The next section describes the methodology, which includes a detailed description of the agricultural modeling system. The third section provides an overview of the baseline projections. A description of the two scenarios and the results from these scenarios are presented in Section 4. The last section summarizes and concludes the paper.

\section{Methodology}

2.1. Description of the FAPRI-CARD Modeling System. The FAPRI-CARD agricultural modeling system is a set of multimarket, partial-equilibrium, and nonspatial econometric models. ${ }^{4}$ The models cover all major temperate crops, sugar, biofuels, dairy, and livestock and meat products for all major producing and consuming countries and are calibrated on the most recently available data (see Table 1). They have been used extensively for generating 10- to 15-year baseline projections for agricultural markets and for policy analysis based on the baseline projections. Data on supply and utilization for the commodities are obtained primarily from the United States Department of Agriculture (USDA) PSD Online and the Food and Agriculture Organization of the United Nations (FAO) FAOSTAT, and macroeconomic historical data and projections are obtained from the International Financial Statistics (IFS) of the International Monetary Fund and IHS Global Insight, respectively. ${ }^{5}$

The commodity models capture the biological, technical, and economic relationships among key variables within a particular commodity and across commodities (see Figure 1$)^{6}{ }^{6}$ They are based on historical data analysis, current academic research, and a reliance on economic, agronomic, and biological relationships in agricultural production and markets. Agricultural and trade policies in each country are included in the model to the extent that they affect the supply and demand decisions of the economic agents. Examples of these include taxes on exports, import tariffs, tariff rate quotas, export subsidies, intervention prices, set-aside rates, and biofuel mandates. Macroeconomic variables, such as gross domestic product (GDP), population, and exchange rates, are exogenous variables that drive the projections in the models. The modeling system has been widely used and extensively validated through many peer-reviewed publications (e.g., [5], Hayes et al., 2009; [12, 13]).

The models specify behavioral equations for production, use, stocks, and trade between countries/regions. The crop supply side is the product of area harvested and yields, wherein the former is determined by a system of land allocation based on the relative expected profitability of competing enterprises (e.g., corn and soybeans) and the latter is driven by an exogenous trend yield as well as intensification and extensification effects. The intensification effect reflects more intensive use of inputs such as fertilizer when revenue grows faster than cost. The extensification effect reflects declining yield as more marginal land is brought into production.

In general, the demand side of the model is categorized into food, feed, and industrial demand, whereby one aspect of industrial demand is the demand from the biofuel sector 


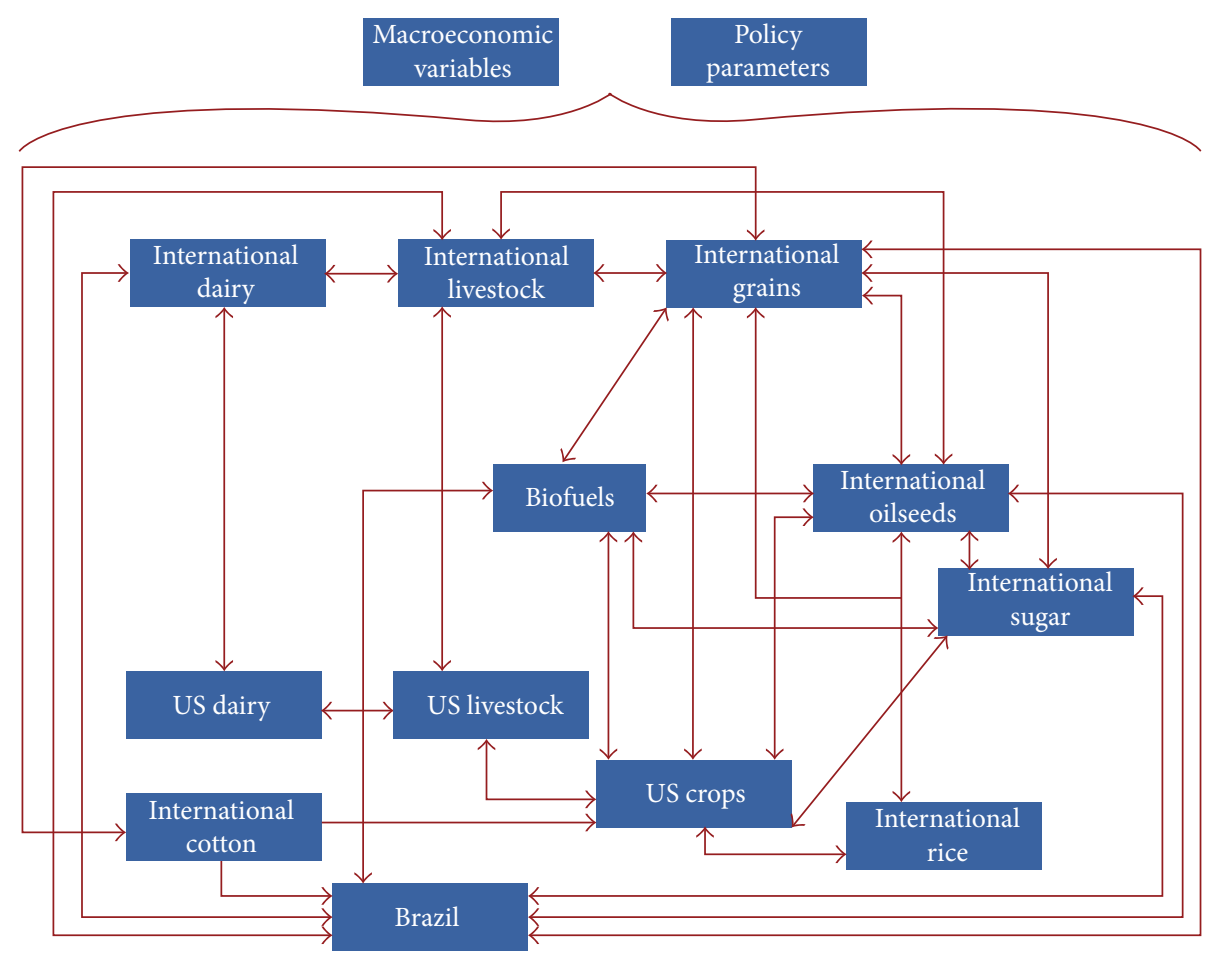

FIGURE 1: FAPRI-CARD model interactions. The model interactions represent trade, prices, and physical flows.

for feedstocks. Food demand is primarily driven by macroeconomic assumptions such as income and population while feed demand is driven by the livestock, poultry, and dairy sectors. Industrial (biofuel) demand is determined by the energy price assumption as well as by existing government policies such as the US EISA 2007 and the Renewable Energy Directive of the European Union. The meat supply side is a combination of investment decisions on the breeding herd and output decisions on slaughter. The animal inventory is the main driver of the feed grain and oilseed meals demand.

For each commodity, a number of countries and regional aggregates are included so as to have worldwide coverage. In general, for each commodity sector, the economic relationship that quantity supplied equals quantity demanded is achieved through a market-clearing price for the commodity. In many countries, domestic prices are modeled as a function of the world price using a price transmission equation, which includes exchange rates and relevant trade policies. As is evident from Figure 1, since the models for each sector can be linked, changes in one commodity sector will impact the other sectors.

The agricultural modeling system also includes a fertilizer component where changes in yields due to intensification are linked to changes in the fertilizer cost. The fertilizer cost is composed of the application rate of nitrogen $(\mathrm{N})$, phosphorous $(\mathrm{P})$, and potassium $(\mathrm{K})$ multiplied by their respective prices. The linkage between yields and fertilizer cost is a function of the yield elasticities with respect to fertilizer application rates and the share of fertilizer cost in the total variable cost. This component also enables us to project fertilizer application rates and fertilizer demand by commodity, by country, and by nutrient. A more detailed explanation of the FAPRI-CARD fertilizer component is available in a paper by Rosas [14].

A model that is able to account for the GHG emissions from agriculture can be linked to the FAPRI-CARD system. The model, called Greenhouse Gases from Agriculture Simulation Model (GreenAgSiM), estimates emissions according to the categories for national GHG inventories established by the Intergovernmental Panel on Climate Change (IPCC). These categories include emissions from enteric fermentation and manure management from livestock, agricultural soil management, rice cultivation, and land-use change. GreenAgSiM consists of two components that use data from the FAPRI-CARD model as inputs. The first is the agricultural production component, which includes enteric fermentation, manure management, rice cultivation, and agricultural soil management. The second is the land-use change component, which captures emissions induced by land-use change occurring if forest and grassland are converted into cropland. With the data derived from the FAPRI-CARD modeling system, the emissions from direct and indirect land-use change can be estimated.

The GHG model tracks six categories of land, namely, forest, shrub land, grass land, set-aside, cropland, and pasture. Pastureland is derived from changes in animal inventory and some historical stocking rate. The algorithm of land dynamics in the model for increases in agricultural land is such that idle land comes into production first. Moreover, a "last in, first out" rule is applied in the conversion of agricultural land. Only when idle land is exhausted will native vegetation be converted into agricultural land. The GHG model also uses 
TABLE 1: FAPRI-CARD model inputs and output.

\begin{tabular}{|c|c|}
\hline Exogenous inputs & $\begin{array}{l}\text { Population, GDP, GDP deflator, } \\
\text { exchange rate, population, policy } \\
\text { variables }\end{array}$ \\
\hline $\begin{array}{l}\text { Historical data } \\
\text { (inputs) }\end{array}$ & $\begin{array}{c}\text { Production, consumption, exports, } \\
\text { imports, ending stocks, Domestic } \\
\text { prices, world prices }\end{array}$ \\
\hline \multicolumn{2}{|l|}{ Commodities } \\
\hline Grains & Corn, wheat, sorghum, barley \\
\hline Oilseeds & soybeans, rapeseed, sunflower \\
\hline Livestock products & beef, poultry, pork \\
\hline Dairy & milk, cheese, butter \\
\hline \multicolumn{2}{|l|}{ Sugar } \\
\hline \multicolumn{2}{|l|}{ Ethanol/biodiesel } \\
\hline \multicolumn{2}{|l|}{ Major countries/regions } \\
\hline North America & United States, Canada, Mexico \\
\hline South America & Brazil, Argentina, and so forth ${ }^{*}$ \\
\hline Asia & $\begin{array}{l}\text { China, Japan, India, Indonesia, } \\
\text { Malaysia, and so forth }\end{array}$ \\
\hline Africa & South Africa, Egypt, and so forth ${ }^{*}$ \\
\hline \multicolumn{2}{|l|}{ European Union } \\
\hline \multicolumn{2}{|l|}{$\begin{array}{l}\text { Australia, } \\
\text { New Zealand }\end{array}$} \\
\hline \multicolumn{2}{|l|}{ Middle East } \\
\hline $\begin{array}{l}\text { Output by commodity } \\
\text { and country }\end{array}$ & $\begin{array}{l}\text { World prices, domestic prices, } \\
\text { production, consumption, net trade, } \\
\text { stocks, area harvested, yield }\end{array}$ \\
\hline
\end{tabular}

${ }^{*}$ In the interest of space, not all 58 countries/regions are listed.

fertilizer application rates and aggregate fertilizer demand information from the FAPRI-CARD model. A more detailed description of this model is given in Dumortier et al. $[8,12]$.

\section{Baseline Results}

3.1. Description of the Baseline. The baseline provides a starting point for evaluating and comparing scenarios. This baseline provides 15-year projections (2011-2025) of world agricultural production, consumption, stocks, trade, and prices by country and commodity. The projections are grounded in a series of assumptions about the general economy, agricultural policies, the weather, and technological change. Specifically, these projections are based on the assumption of average weather patterns, existing farm policy, and policy commitments under current trade agreements and custom unions. They also generally assume that current agricultural policies will remain in force in the United States and in other trading nations during the projection period.

Bioenergy mandates in a number of countries are key drivers in the baseline. In the United States, the Renewable Fuel Standard (RFS) and other provisions of EISA 2007 are implemented, with the exception of the cellulosic ethanol RFS (because of waivers). The existing US biofuel mandates are binding in the baseline. Another key assumption is that ethanol and biodiesel support policies in the United States disappear in 2012. These include ethanol and biodiesel tax credits and biofuel import tariffs. ${ }^{7}$ In addition, the Food, Conservation, and Energy Act (FCEA) of 2008 in the United States and the current provisions of the Common Agricultural Policy in the European Union are included in the baseline.

Additionally, long-run equilibrium is imposed in the ethanol sector in the United States as well as in the international livestock and dairy sectors. In the long run, in equilibrium, there is no incentive to build new ethanol plants and there is no incentive to shut down existing plants. This means that the profit margins of the ethanol plants are zero in the long run. In the livestock and dairy sectors, supply and prices adjust so that net returns go back to "normal" levels in the long run; that is, the returns are at levels sufficient to keep producers in business. This long-run equilibrium is imposed in the year $2023 .^{8}$

3.2. Macroeconomic Environment. The baseline projections are run against a backdrop of a macroeconomic environment that includes an economic turnaround, which began in 2010, continuing population growth and urbanization and ever-expanding biofuel mandates such as EISA 2007 in the United States and the Renewable Energy Directive of the European Union. ${ }^{9}$ GDP grows in the United States, Canada, and Mexico by a range of $2.5 \%$ to $4 \%$ over the projection period. Asian economies lead the world economic recovery with aggressive stimulus policies, resumed capital inflow, and industrial growth momentum. China, Vietnam, and India post solid growth of between $7 \%$ and $8 \%$. Annual growth in Argentina and Brazil is projected to average $3.6 \%$ and $4.4 \%$, respectively. Growth in the European Union averages $1.9 \%$ over the projection period.

\subsection{Baseline Projections}

3.3.1. Agricultural Markets. Overall, throughout the projection period, agricultural markets are impacted by increasing demand and higher prices driven by income growth, population growth, and expanding demand for biofuel feedstocks. Table 2 shows the baseline prices for the major commodities for 2011, the first year of the projection, and 2023, which is the year the long-run equilibrium is imposed. ${ }^{10}$

In the baseline, the world corn prices are driven by both strong demand from various uses of corn, which leads to an increase in price, and growth in trend yields and the capping of the RFS by 2015. This results in a downward pressure on prices. Thus, corn prices remain fairly flat over the projection period, increasing to $\$ 200$ per metric ton by 2023 . Corn trade grows by $4 \%$ annually over the decade. Corn used as ethanol feedstock also increases with rising mandates in several countries. For example, Canada's ethanol feedstock represents $20 \%$ of its total domestic use, the European Union, $12 \%$, and the United States, 39\%. Other grains follow the same pattern as corn, whereby both prices and net trade rise over the projection period.

Because of rising incomes, strong demand, mostly for vegetable oils for food and biodiesel use, sustains the prices 
TABLE 2: Baseline prices for major commodities.

\begin{tabular}{lcc}
\hline & 2011 & Long run $^{*}$ \\
\hline & (US dollars per metric ton) \\
Wheat FOB Gulf & 270 & 274 \\
Corn FOB Gulf & 183 & 200 \\
Soybean CIF Rotterdam & 442 & 475 \\
Beef Nebraska Direct & 2,274 & 2,530 \\
Barrow and Gilt, National & 1,226 & 1,463 \\
Broiler U.S. 12-City & 1,924 & 2,256 \\
& (US dollars per gallon) \\
Anhydrous ethanol, Brazil & 1.63 & 2.60 \\
Ethanol FOB Omaha & 1.97 & 2.04 \\
Biodiesel Central Europe FOB & 4.77 & 5.81 \\
US biodiesel plant & 4.22 & 4.84 \\
\hline
\end{tabular}

${ }^{*}$ Long-run equilibrium is imposed in 2023.

of oilseeds and their products at high levels. Crush is increasingly driven by the demand of vegetable oil, which pressures soybean meal prices downward by the end of the period.

3.3.2. Fertilizer Use. World fertilizer use increases $5 \%$ by 2023 relative to the 2010 crop season, reflecting the expansion of the world's cropland. Higher use is also driven by the more intensive use of fertilizers at the world level in commodities such as corn, barley, rapeseed, peanuts, and cotton, driven by their strong prices. World fertilizer use in corn is projected to be higher in NPK relative to 2010 because of the increase in both corn harvested areas and fertilizer application rates. This is especially true for the United States, the world's second largest fertilizer consuming country (after China). The use of $\mathrm{P}$ and $\mathrm{K}$ increases by a larger percentage relative to $\mathrm{N}$ because of their higher elasticity with respect to corn price changes. World fertilizer use in soybeans has similar levels of $\mathrm{N}$ and increases of 5\% and $2 \%$ in $\mathrm{P}$ and $\mathrm{K}$, respectively, relative to 2010. This is caused by the increase in global soybean harvested area that offsets the decrease in nutrient application rates per hectare. China, India, the United States, and the EU countries account for more than two-thirds (65\%) of the world's fertilizer consumption in agriculture.

3.3.3. Greenhouse Gas Emissions. Increased fertilizer use has significant implications on GHG emissions as is evident from Figure 2 for the United States. The map presents the projected percentage increase in $\mathrm{N}_{2} \mathrm{O}$ emissions from US agricultural soil management synthetic fertilizer use for the baseline between 2011 and 2025. The Corn Belt region (Iowa, Illinois, and Indiana), where mostly corn and soybeans are grown and corn area is increasing, is projected to increase its emissions of $\mathrm{N}_{2} \mathrm{O}$ by $6 \%$ or more over the projection period. In the Northern Plains region (North Dakota, South Dakota, and Montana), where barley and wheat are grown, but area is decreasing over the projection period, emissions from $\mathrm{N}_{2} \mathrm{O}$ are projected to decline between 2011 and 2025.

The expansion in crop area as well as the rise in meat demand and the resulting expansion in livestock increases emissions from livestock products (especially enteric fermentation) and puts pressure on global forests and grasslands. We estimate that global emissions from agricultural production rise by $14 \%$ over the projection period.

\section{Scenario Results}

4.1. Description of the Scenarios. Once the baseline is established, specific scenarios are run and the results are compared to the baseline. The first scenario is a fertilizer scenario in which a nitrogen tax increases the price of nitrogen in the United States by $10 \%$ over the baseline beginning in 2011 and extending to the final projection year of 2025 .

In the second scenario, a US afforestation scenario is analyzed in which we use the crop area displacement from afforestation used in a report by the United States Department of Agriculture [3]. The scenario replaces 50 million acres of cropland with forests mostly in the Corn Belt. This reduction is equivalent to a $15 \%$ decrease in the total cropland used for the 13 major crops, hay, and Conservation Reserve Program (CRP). Given high commodity prices and the resulting high land cash rents in the Corn Belt, we believe that it is very unlikely to see significant afforestation in the Corn Belt as modeled in the USDA 2009 report [15]. However, we adopt the scenario of high afforestation in the Corn Belt because it leads to interesting results in terms of prices and agricultural production around the world. In addition, it illustrates the negative effects in terms of carbon sequestration by shifting agricultural production from the United States to other countries.

The two scenarios are presented relative to the baseline projections by comparing the long-run equilibrium results for the baseline (year 2023) to those of the scenarios. The impacts on US and world crops and livestock (i.e., agricultural markets), biofuels, and fertilizer are expressed in terms of percent change between the 2023 baseline and scenario numbers. The only exception is the impact on GHG emissions, which are presented in terms of the average percent change over the projection period. Emissions, particularly for land-use change, are nonlinear and vary significantly from year to year. Thus, average changes over the projection period tend to be more informative than choosing one particular year.

\subsection{Fertilizer Tax Scenario}

4.2.1. Impact on Agricultural Markets. We analyze a fertilizer tax scenario in which the tax increases the price of nitrogen in the United States by 10\% over the baseline from 2011 to 2025. US farmers usually apply more nitrogen than they need in a typical year. They do this because they realize that nitrogen can leach in wet years and that it therefore makes economic sense to apply excess nitrogen to insure against wet spring weather [16]. That is, when nitrogen fertilizer is inexpensive relative to its value when it is needed, farmers will apply more fertilizer than is needed in an average year. Additionally, Sheriff [17] suggests that overapplication of nitrogen fertilizer is ex ante optimal. Recent research suggests 


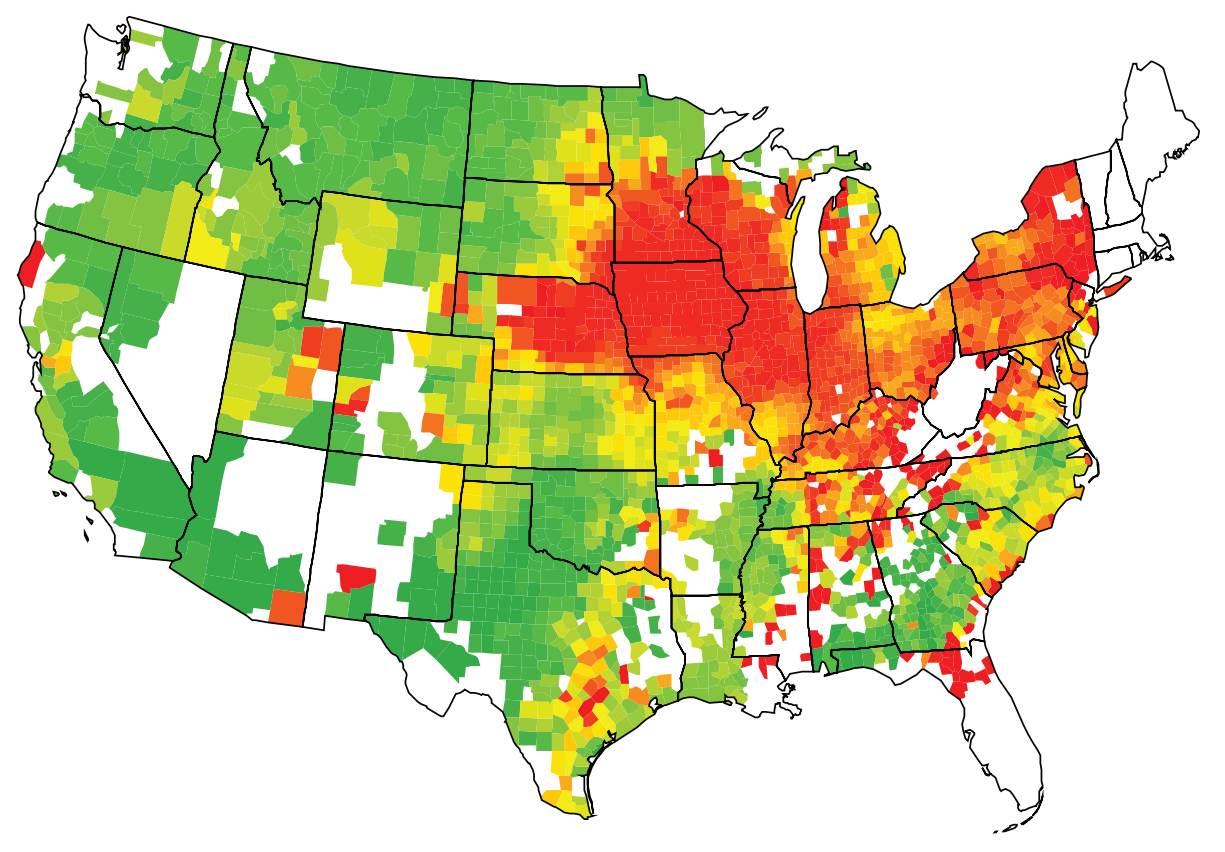

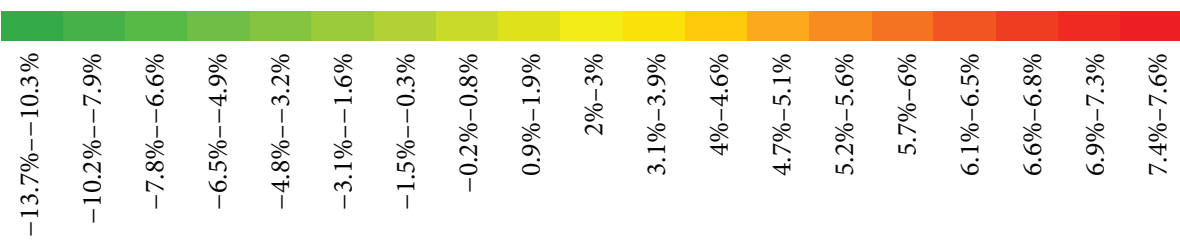

FIGURE 2: Baseline change in US nitrous oxide emissions between 2011 and 2025.

that $\mathrm{N}_{2} \mathrm{O}$ emissions increase dramatically when nitrogen fertilizer rates exceed agronomic rates.

To put the magnitude of this shock in perspective, total fertilizer cost accounts for almost $40 \%$ of corn total variable cost in the US Corn Belt region, and the cost of nitrogen fertilizer represents about $50 \%$ of total fertilizer cost. In soybeans, total fertilizer cost accounts for $28 \%$ of total variable cost, and the cost of nitrogen fertilizer represents $9 \%$ of total fertilizer cost [18]. ${ }^{11}$ Therefore, a $10 \%$ increase in the price of nitrogen fertilizer translates into an increase in variable costs in the Corn Belt in the order of roughly $2 \%$ and $0.25 \%$ for corn and soybeans, respectively. The change in the total variable cost directly affects both the area allocation and yield equations. Although the impacts are small, as expected, some interesting results emerge. As illustrated in the case of corn and soybeans, there will be some differentials in the impacts across different crops because of the varying intensity of the use of fertilizer in general and nitrogen fertilizer in particular. Additionally, since this is a shock only in the United States, there are offsetting effects when the response of the rest of the world is considered.

Table 3 shows the impacts of the increase in the price of nitrogen fertilizer on the price of the major commodities by comparing baseline numbers to scenario numbers. As shown in Table 3, corn and wheat prices increase while soybean prices decline. This follows from the observation that corn and wheat make more intensive use of nitrogen fertilizer than
TABle 3: Change in commodity prices between baseline and fertilizer tax scenario.

\begin{tabular}{lcc}
\hline & $2011^{*}$ & Long run $^{* *}$ \\
\hline Wheat FOB Gulf & $0.11 \%$ & $0.09 \%$ \\
Corn FOB Gulf & $0.25 \%$ & $0.14 \%$ \\
Soybean CIF Rotterdam & $-0.07 \%$ & $-0.05 \%$ \\
Beef Nebraska Direct & $0.01 \%$ & $0.01 \%$ \\
Barrow and Gilt, National & $0.01 \%$ & $0.08 \%$ \\
Broiler U.S. 12-City & $0.01 \%$ & $0.03 \%$ \\
Anhydrous ethanol, Brazil & $0.004 \%$ & $0.01 \%$ \\
Ethanol FOB Omaha & $0.05 \%$ & $0.08 \%$ \\
Biodiesel Central Europe FOB & $0.00 \%$ & $-0.01 \%$ \\
Biodiesel plant & $-0.01 \%$ & $-0.02 \%$ \\
\hline
\end{tabular}

${ }^{*} 2011$ is the first year of projection. ${ }^{* *}$ Long-run equilibrium is imposed in 2023.

do soybeans, and therefore their costs increase more as a result of the fertilizer price increase. The improvement of the economic returns of soybeans relative to those of corn and wheat leads to an expansion of the soybean area in the United States at the expense of the grains. As a result, soybean prices go down while wheat and corn prices go up. The table also shows that the price movement of ethanol follows that of corn, the major feedstock in the United States.

Table 4 shows the impact on production and net trade for the year 2023 when long-run equilibrium is imposed. 
TABLE 4: Changes in production and net trade between baseline and fertilizer tax scenario (2023).

\begin{tabular}{lcc}
\hline & Production & Net trade \\
\hline United States & & \\
Wheat & $-0.19 \%$ & $-0.45 \%$ \\
Corn & $-0.18 \%$ & $-0.52 \%$ \\
Soybeans & $0.07 \%$ & $0.11 \%$ \\
Beef & $0.001 \%$ & $0.09 \%$ \\
Pork & $-0.07 \%$ & $-0.29 \%$ \\
Broiler & $0.001 \%$ & $0.02 \%$ \\
Ethanol & $0.0003 \%$ & $0.001 \%$ \\
Biodiesel & $0.02 \%$ & $-4.15 \%$ \\
Rest of the world & & \\
Wheat & $0.01 \%$ & $0.07 \%$ \\
Corn & $0.07 \%$ & $0.50 \%$ \\
Soybeans & $-0.02 \%$ & $-1.53 \%$ \\
Beef & $-0.004 \%$ & $-0.01 \%$ \\
Pork & $0.02 \%$ & $0.05 \%$ \\
Broiler & $-0.003 \%$ & $-0.01 \%$ \\
Ethanol & $-0.002 \%$ & $0.001 \%$ \\
Biodiesel & $0.002 \%$ & $-0.01 \%$ \\
\hline
\end{tabular}

The reduced supply of corn and wheat in the United States, resulting from an increase in the cost of production, leads to a reduction in US net exports of these commodities and higher prices. Conversely, the rest of the world responds to the lower US exports and higher prices by raising their production levels of corn and wheat, leading to smaller changes in net exports. Interestingly, production of soybeans declines in the rest of the world. That is, production changes for these three commodities (wheat, corn, and soybeans) in the rest of the world are directionally opposite those of the United States. The intuition behind these results is that cost of production does not change for the rest of the world; therefore, production responses follow the price movements. On the other hand, changes in the costs of fertilizer in the United States worsen the domestic competitiveness of wheat and corn compared with that of soybeans.

The impacts on biofuel and livestock production and trade are also presented in Table 4 . Higher production costs lead to an increase in corn prices. However, US ethanol production is relatively unchanged in 2023 relative to the baseline. Despite the higher world ethanol price, ethanol production in countries like Canada and China also declines as prices for the feedstock for ethanol (viz., corn and wheat) increase. Although US biodiesel net imports decline by $4 \%$ in 2023, net imports are only 4.3 million gallons in the baseline, decreasing to 4.1 million gallons in the scenario. For livestock products, beef is slightly favored when compared with pork and poultry. This is because soybean meal and hay prices decline for beef cattle, while hogs are penalized by the higher feed cost, particularly for corn. The rest of the world responds by compensating for any reduction in pork trade from the United States.

With a binding ethanol RFS, the higher corn feedstock price induces a substitution of imported sugarcane ethanol

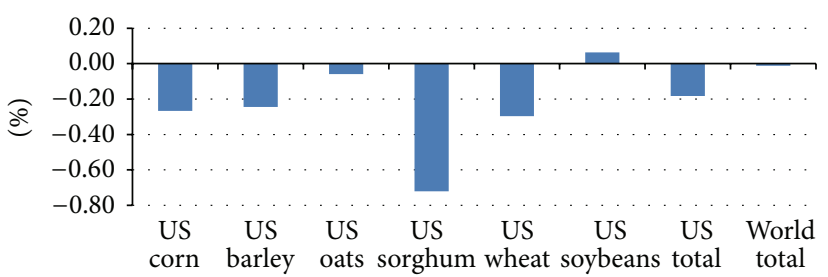

FIGURE 3: Change in fertilizer use between baseline and fertilizer tax scenario (2023).

for domestic corn ethanol and higher ethanol prices. In contrast, the cheaper soybean oil biodiesel feedstock leads to higher domestic production of biodiesel, despite lower prices for the product.

4.2.2. Impact on Fertilizer Use. Figure 3 shows that total fertilizer use in the United States decreases by just under $0.2 \%$ because the higher domestic price of fertilizer induces a decrease in fertilizer application rates and planted areas of most commodities (except for soybeans and sugar beet).

In the case of corn production, higher nitrogen prices drive down harvested areas, as well as fertilizer application rates, decreasing total fertilizer use in corn. This result shows the inelasticity of demand for fertilizers in corn. A $10 \%$ increase in the price of nitrogen has only minor longrun effects on nitrogen demand. A similar result of lower planted area and lower fertilizer application rates occurs in other grains such as barley, oats, sorghum, and wheat. In contrast, soybeans show an increase in fertilizer use even with a lower fertilizer application rate because area is shifted from nitrogen-intensive crops. Soybean production is characterized by a low use of nitrogen fertilizers because of the crop's ability to fix nitrogen in soils from other sources. Thus, an increase in the price of nitrogen is expected to make soybean production relatively more attractive.

Since the nitrogen fertilizer price increase is isolated to the United States, the rest of the world responds to the higher world crop prices by increasing area and rates of fertilizer use, but the impacts are small. The overall consequence of such a policy is that the reduction in demand from US nitrogen-intensive crops such as corn, barley, oats, and wheat is partially offset by the higher use in the rest of the world such that world fertilizer use shows only a minor reduction.

The CARD-FAPRI model includes landed prices for each country expressed in US dollars per metric ton of nitrogen, phosphate, and potash units, that is, expressed in nutrient units. Table 5 shows baseline and scenario reference prices for three fertilizer products in the US case. While this number may seem small when compared to the sharp changes in fertilizer prices in recent years, it is relatively large with respect to existing fertilizer taxes. To put this figure in perspective, consider that through the 1987 Groundwater Protection Act (House File 631) for Iowa, in articulation of its comprehensive policy of groundwater contamination, a nitrogen tax of $\$ 0.75$ per ton of product ( $\$ 0.82$ per metric ton) was established based on an $82 \%$ nitrogen content solution. In the case of urea (with $46 \%$ of nitrogen content), for example, the nitrogen tax represents a $0.1 \%$ increase in the price. 
TABLE 5: US fertilizer landed prices: baseline and fertilizer tax scenario (US\$/metric ton).

\begin{tabular}{lcccccccccccccc}
\hline & 2011 & 2012 & 2013 & 2014 & 2015 & 2016 & 2017 & 2018 & 2019 & 2020 & 2021 & 2022 & 2023 & Avg. \\
\hline & & & \multicolumn{10}{c}{ Baseline } \\
Urea & 440 & 459 & 473 & 473 & 481 & 486 & 487 & 492 & 500 & 508 & 508 & 508 & 508 & 486 \\
Super phosphate & 509 & 529 & 552 & 563 & 580 & 590 & 597 & 607 & 617 & 627 & 627 & 627 & 627 & 589 \\
Potassium chloride & 513 & 533 & 556 & 568 & 585 & 594 & 602 & 612 & 622 & 632 & 632 & 632 & 632 & 593 \\
\hline & & & \multicolumn{10}{c}{ Fertilizer tax scenario } \\
Urea & 484 & 505 & 520 & 520 & 529 & 534 & 535 & 541 & 550 & 559 & 559 & 559 & 559 & 535 \\
Super phosphate & 509 & 529 & 552 & 563 & 580 & 590 & 597 & 607 & 617 & 627 & 627 & 627 & 627 & 589 \\
Potassium chloride & 513 & 533 & 556 & 568 & 585 & 594 & 602 & 612 & 622 & 632 & 632 & 632 & 632 & 593 \\
\hline
\end{tabular}

4.2.3. Impact on Greenhouse Gas Emissions. In terms of livestock and associated emissions, with the lower prices of soybean meal and hay offsetting the increase in the price of corn, there are no significant changes in GHG emissions from enteric fermentation and manure management.

The more interesting aspect of the scenario is the inability of the $10 \%$ fertilizer price increase to significantly reduce synthetic fertilizer emissions (nitrogen) in the United States. Over the projection period, emissions in the United States decline by an average of only $0.15 \%$ and also on a global scale the reductions are negligible. ${ }^{12}$ An explanation for this phenomenon can be found in the fairly inelastic demand for nitrogen fertilizer in the United States. The scenario restricts the effects of the fertilizer price increase to the United States. That is, there is no transmission of the higher nitrogen fertilizer price in the United States to the fertilizer price in the rest of the world. Area in the United States goes down by $0.07 \%$ on average, leading other countries to compensate for the reduced production by increasing their area. Table 6 depicts the increase in million metric tons of $\mathrm{CO}_{2}$-equivalent for selected countries and for the rest of the world. Land carbon sequestration increases by $1.63 \%$ in the United States due to the reduction in cropland.

However, the increase in global crop area is small and leads to only slightly higher emissions when compared with the baseline. Carbon savings from land reversion in the United States may not be significant because reverted cropland goes into idle cropland category. However, land conversion in the rest of the world may be from native vegetation rich with sequestered carbon. The two main drivers of those emissions are India and China, both having low available idle land and a greater likelihood of conversion of native vegetation to supply increases in cropland.

\subsection{Afforestation Scenario}

4.3.1. Impact on Agricultural Markets. In order to analyze the impact of the afforestation scenario, we used the crop area displacement from afforestation used by the EPA in its 2005 report, which projects the afforestation of roughly 100 million acres of land in the United States under the scenario of $\$ 30$ per metric ton of carbon and 50 million acres of displaced area from cropland (Table 7). This displacement is equivalent to a $15 \%$ reduction in the total cropland used for the 13 major crops, hay, and CRP. The acres were reduced by crop based on
TABLE 6: Change in land carbon sequestration between baseline and fertilizer tax scenario.

\begin{tabular}{lcc}
\hline Country & Change in $\mathrm{Mt}$ of $\mathrm{CO}_{2}$-e & Change in $\%$ \\
\hline Argentina & -0.067 & $-0.10 \%$ \\
Brazil & 0.122 & $0.02 \%$ \\
China & 0.414 & $0.38 \%$ \\
European Union & 0.135 & $0.19 \%$ \\
India & 1.327 & $0.69 \%$ \\
United States & -1.548 & $1.63 \%$ \\
Rest of the world & 1.314 & $0.09 \%$ \\
\hline Total & 1.697 & $0.07 \%$ \\
\hline
\end{tabular}

TABLE 7: Initial area reduction by region in the United States (in million acres).

\begin{tabular}{lcccc}
\hline Regions & 2011 & 2015 & 2020 & 2025 \\
\hline Corn Belt & 3.57 & 10.71 & 19.64 & 25.00 \\
Delta States & 2.29 & 6.86 & 12.57 & 16.00 \\
Far West & 0.14 & 0.43 & 0.79 & 1.00 \\
Lake States & 0.21 & 0.64 & 1.18 & 1.50 \\
Southeast & 0.21 & 0.64 & 1.18 & 1.50 \\
Southern Plains & 0.71 & 2.14 & 3.93 & 5.00 \\
\hline Total & 7.14 & 21.43 & 39.29 & 50.00 \\
\hline
\end{tabular}

area share by region and each crop's share of total area within each region in the baseline. Even though 50 million acres were originally displaced, the total of 13 crops, hay, and CRP in the scenario is only 40 million acres below the baseline. ${ }^{13}$ The primary reason is that, as cropland is displaced, crop prices and revenue increase, encouraging some retention of area. Of the 40 million acres of displaced area, $40 \%$ is in soybeans, $22 \%$ in corn, $13 \%$ in wheat, $12 \%$ in hay, $5 \%$ in rice, $3 \%$ in cotton, and $2 \%$ in sorghum.

Table 8 shows the percent change in the prices of selected commodities in the crop, livestock, and biofuel sectors between the baseline and the afforestation scenario. We find in this scenario an increase in the prices of all agricultural commodities, as more land is reverted to forestland use, first contracting agricultural supply in crops, then in all other commodities, including, biofuels, livestock, and fertilizer. The initial shock in the United States creates a short supply situation, causing prices to increase by $10.5 \%$ for wheat and by $17 \%$ for corn. 
TABLE 8: Change in commodity prices between baseline and afforestation scenario.

\begin{tabular}{lcc}
\hline & $2011^{*}$ & Long run $^{* *}$ \\
\hline Wheat FOB Gulf & $1.42 \%$ & $10.51 \%$ \\
Corn FOB Gulf & $3.60 \%$ & $17.12 \%$ \\
Soybean CIF Rotterdam & $3.45 \%$ & $18.48 \%$ \\
Beef Nebraska Direct & $0.10 \%$ & $6.78 \%$ \\
Barrow and Gilt, National & $0.25 \%$ & $9.99 \%$ \\
Broiler U.S. 12-City & $0.28 \%$ & $9.91 \%$ \\
Anhydrous ethanol, Brazil & $0.06 \%$ & $0.24 \%$ \\
Ethanol FOB Omaha & $0.62 \%$ & $7.84 \%$ \\
Biodiesel Central Europe FOB & $0.16 \%$ & $3.65 \%$ \\
Biodiesel plant & $0.33 \%$ & $6.48 \%$ \\
\hline
\end{tabular}

${ }^{*} 2011$ is the first year of projection. ${ }^{* *}$ Long-run equilibrium is imposed in 2023.

Based on the EPA area displacement estimate, most of the cropland area converted into forest land is from soybean area. As a result, with a short supply, the soybean price increases by $18.5 \%$. In the livestock sector, the strong feed grain and oilseed meal prices resulting from afforestation lead to a general short supply of meat, causing prices to rise for beef, pork, and poultry.

Table 9 shows the impact of the afforestation scenario on domestic production and net trade. As more cropland is diverted for afforestation in the United States, more area is planted in the rest of the world. That is, while area planted for wheat and corn declines in the United States, area for these crops increases outside the United States. In effect, the price impacts relocate agricultural production away from the United States and toward the rest of the world.

Similarly, afforestation of soybean area in the United States increases soybean area in the rest of the world, with production in Argentina and Brazil increasing. In the livestock sector, the strong feed grain and oilseed meal prices resulting from afforestation contract the US livestock and poultry sectors. Total world production impacts for all meats reflect the differential feed cost structure, whereby beef production responds much less than poultry production to the increase in feed prices.

With the area displacement, US exports of corn and wheat decline. The rest of the world responds to the short supply and higher grain prices, with China reducing corn imports and Brazil and South Africa increasing their corn exports. In the case of wheat, China and Russia increase their net wheat exports. As most of the cropland area converted into forest land is from soybean area, soybean production in the United States declines with decline in both area and yields. Moreover, yield declines suggest a decreasing share of high-yield regions in total US production. With a short supply, US soybean exports are reduced. In the livestock sector, net imports of beef increase while exports of pork and poultry decline. Because of their different feeding rations and associated cost structures, the beef sector gains in relative terms compared with pork and poultry when prices of feeds increase, as consumers substitute away from the relatively more expensive pork and poultry.
TABLE 9: Change in production and net trade between baseline and afforestation scenario (2023).

\begin{tabular}{lcc}
\hline & Production & Net trade \\
\hline United States & & \\
Wheat & $-11.20 \%$ & $-25.14 \%$ \\
Corn & $-10.31 \%$ & $-31.38 \%$ \\
Soybeans & $-22.85 \%$ & $-35.97 \%$ \\
Beef & $-6.95 \%$ & $118.31 \%$ \\
Pork & $-4.69 \%$ & $-19.49 \%$ \\
Broiler & $-6.01 \%$ & $-14.69 \%$ \\
Ethanol & $-0.02 \%$ & $0.08 \%$ \\
Biodiesel & $-4.66 \%$ & $1082.43 \%$ \\
Rest of the world & & \\
Wheat & $0.49 \%$ & $3.53 \%$ \\
Corn & $3.91 \%$ & $43.90 \%$ \\
Soybeans & $6.52 \%$ & $15.73 \%$ \\
Beef & $0.66 \%$ & $2.52 \%$ \\
Pork & $2.61 \%$ & $3.02 \%$ \\
Broiler & $1.75 \%$ & $3.00 \%$ \\
Ethanol & $-0.06 \%$ & $0.21 \%$ \\
Biodiesel & $-0.60 \%$ & $0.24 \%$ \\
\hline
\end{tabular}

${ }^{*}$ Biodiesel imports increase from 4.3 million gallons to 50.7 million gallons between the baseline and the scenario.

4.3.2. Impact on Greenhouse Gas Emissions. The afforestation scenario represents a major shift in US agricultural production, and we see that the unintended consequence of this policy is an increase in carbon emissions from landuse change on a global scale. In Table 10, which shows the change in emissions between the baseline and the scenario, we separate the emissions of synthetic fertilizer from agricultural soil management (ASM) emissions to underline the effect of the emissions from fertilizer in the fertilizer tax scenario. Although there is a reduction in emissions from synthetic fertilizer in the United States, emissions from landuse change due to a shift of agricultural production to other countries outweigh the savings in the United States.

Emissions from enteric fermentation decrease for all major countries as most livestock and dairy sectors contract under a high feed regime with afforestation, the sharpest decrease occurring in the United States (1.04\%). Emissions from nitrogen application are reduced by $0.39 \%$ on a global scale. The main driver of this result is the US cropland reduction, although fertilizer consumption in most other countries increases. For example, total fertilizer emissions increase by $0.86 \%$ in Brazil, by $0.7 \%$ in China, and by $0.27 \%$ in the European Union. The most interesting aspect of the scenario is the increase in carbon emissions related to landuse change in the rest of the world. High-quality US cropland is replaced with lower quality cropland (quality in terms of yield), and, hence, more area is needed to compensate for the reduction in production. We see cropland increase in almost all countries, including in Brazil (0.21\%) and in China $(0.64 \%)$. Because many of these countries have exhausted their idle cropland, any increase in cropland is likely to be supplied by converting land covered by native vegetation, 
TABLE 10: Change in emissions between baseline and afforestation scenario.

\begin{tabular}{|c|c|c|c|c|c|}
\hline & Enteric fermentation & Manure management & Synthetic fertilizer & ASM (except fertilizer) & LUC emission \\
\hline & \multicolumn{5}{|c|}{ (Million metric tons of $\mathrm{CO}_{2}$-equivalent) } \\
\hline Argentina & -0.01 & -0.01 & 0.03 & 0.15 & 6.50 \\
\hline Brazil & -0.02 & 0.03 & 0.09 & 1.30 & 140.51 \\
\hline China & -0.30 & -0.01 & 0.68 & 1.51 & 31.54 \\
\hline European Union & -0.04 & -0.01 & 0.11 & 0.07 & 8.45 \\
\hline India & -0.03 & 0.00 & -0.05 & -0.02 & 3.46 \\
\hline United States & -1.23 & -0.54 & -2.77 & -3.48 & -158.95 \\
\hline Rest of the world & 0.35 & 0.14 & 0.57 & 1.05 & 114.24 \\
\hline \multirow[t]{2}{*}{ World } & -1.29 & -0.40 & -1.35 & 0.58 & 145.75 \\
\hline & \multicolumn{5}{|c|}{ (Percent change) } \\
\hline Argentina & $-0.02 \%$ & $-0.18 \%$ & $0.81 \%$ & $0.18 \%$ & $9.95 \%$ \\
\hline Brazil & $-0.01 \%$ & $0.12 \%$ & $0.86 \%$ & $0.51 \%$ & $24.05 \%$ \\
\hline China & $-0.17 \%$ & $-0.01 \%$ & $0.70 \%$ & $0.41 \%$ & $29.29 \%$ \\
\hline European Union & $-0.03 \%$ & $-0.02 \%$ & $0.27 \%$ & $0.09 \%$ & $12.21 \%$ \\
\hline India & $-0.02 \%$ & $-0.01 \%$ & $-0.10 \%$ & $-0.04 \%$ & $1.79 \%$ \\
\hline United States & $-1.04 \%$ & $-1.37 \%$ & $-6.43 \%$ & $-1.62 \%$ & $167.27 \%$ \\
\hline Rest of the world & $0.07 \%$ & $0.11 \%$ & $0.60 \%$ & $0.14 \%$ & $7.71 \%$ \\
\hline World & $-0.09 \%$ & $-0.11 \%$ & $-0.39 \%$ & $0.03 \%$ & $6.06 \%$ \\
\hline
\end{tabular}

leading to a $6.65 \%$ increase in global emissions from land-use change compared with the baseline.

\section{Summary and Conclusion}

This analysis evaluates the impact of two policy scenarios on US and world agricultural markets, as well as on world fertilizer use and world agricultural greenhouse gas emissions. Both scenarios are adverse supply shocks, the first being a 10\% increase in the price of nitrogen fertilizer in the United States, and the second a reversion of US cropland into forestland.

At the end of the baseline projection period, the United States accounts for $18 \%$ of the world's idle cropland, Brazil $43 \%$, Russia $10 \%$, and Mexico $9 \%$. Many of the remaining countries have almost exhausted their idle cropland, including Argentina with only 0.09 million hectares, Australia with 0.46 , Canada with 1.30 , China with 0.97 , India with 0.02 , and South Africa with 0.04. This situation is important because, in effect, any shock penalizing the United States in the sense of reducing US cropland and thereby reducing US exports may result in unintended consequences elsewhere, with countries that are short of cropland responding to this new market incentive and expanding domestic production by converting native vegetation, thus releasing rich carbon stock.

In the livestock sector, the most interesting lesson from the scenarios is that they have a differential impact by meat type because of differences in cost structures across sectors. That is, feed cost accounts for only $28 \%$ of the total cost in a cow-calf operation while it accounts for $74 \%$ of a pork farrowto-finish operation. Any shock in the United States that raises crop prices will automatically result in relatively higher price changes in pork and poultry compared with beef, which sustains domestic beef consumption through substitution and weakens any reduction of the beef sector from the higher crop prices. Also, pasture-based production systems in other countries may not be too adversely affected by higher grain prices, allowing expansion in world beef production and an increase in world GHG emissions.

The impact of a policy that raises nitrogen fertilizer prices on GHG emissions is muted when the entire agricultural sector in the world market is allowed to adjust. For example, although fertilizer-intensive crops (such as corn) are penalized with higher nitrogen fertilizer prices resulting in lower fertilizer use, more fertilizer is used in the same crops in the rest of the world. Moreover, market rigidities caused by policies dull the impact of higher nitrogen fertilizer prices. This is particularly true in biofuels, which have a binding RFS in both ethanol and biodiesel production in the baseline. Higher corn feedstock prices reduce domestic production of ethanol. But because the RFS is binding, any reduction in domestic corn ethanol is simply replaced by an increase in the imports of sugarcane ethanol from Brazil, thereby raising the world ethanol price, sugarcane area, and sugarcane fertilizer use.

In the afforestation scenario, crop production shifts from high-yielding land in the United States to low-yielding land in the rest of the world. Additionally, there is an increased likelihood that land with native vegetation will be converted into cropland. The net impact is an unintended increase in world greenhouse gas emissions.

In general, the results show that the entire international commodity market system is robust with respect to policy changes in one country or in one sector. The policy implication is that domestic policy changes implemented by a large agricultural producer like the United States can have fairly significant impacts on the aggregate world commodity markets. A second point that emerges from the results is that the law of unintended consequences is at work in world agriculture. For example, a policy geared toward sequestering 
carbon through afforestation in the United States can end up resulting in a net increase in world greenhouse gas emissions.

The results suggest that to avoid the kind of leakage resulting from the unilateral implementation of policies in a major agricultural producer (like the United States) internationally coordinated policies and actions might be needed. An analysis of alternative concerted policy actions (e.g., simultaneous implementation of the nitrogen tax in all countries of the world), particularly in terms of their ability to more effectively reduce emissions, might be an interesting avenue for future research.

\section{Endnotes}

1. Data on the world crude oil price is from the World Bank [19] (simple average of three spot prices; Dated Brent, West Texas Intermediate, and the Dubai Fateh in nominal US dollars).

2. More details on ACES and EISA can be found at http:// thomas.loc.gov/cgi-bin/bdquery/z?d111:H.R.2454: and http://www.gpo.gov/fdsys/pkg/PLAW-110publ140/html/ PLAW-110publ140.htm, respectively.

3. FAPRI is the Food and Agricultural Policy Research Institute at Iowa State University.

4. We call the modeling system FAPRI-CARD to distinguish it from the FAPRI system, which involves a model of the US agricultural sector developed and maintained by the University of Missouri at Columbia and international models developed and maintained at Iowa State University. In the FAPRI-CARD system, both the domestic and international models are maintained at Iowa State University.

5. Links to these sources are available: for USDA PSD Online: http://www.fas.usda.gov/psdonline/; for FAOSTAT: http://faostat.fao.org/ ; for IFS: http://www.imf .org/external/data.htm for IHS Global Insight: http:// www.ihs.com/products/global-insight/index.aspx?pu=1 \&rd=globalinsight_com/.

6. For a more detailed description of each of the models, see http://www.fapri.iastate.edu/models/.

7. This turns out to be the case for ethanol. However, the blender's tax credit for biodiesel was extended again in early 2013.

8. Although the projections extend to 2025, we impose the long-run equilibrium in 2023 to allow the models an additional couple of years to adjust.

9. This baseline is the FAPRI-ISU World Agricultural Outlook, available at http://www.fapri.iastate.edu/outlook/2011/.

10. More detailed tables on the baseline and scenario results by country are available from the authors.

11. The USDA's Economic Research Service provides data on fertilizer use by crop and by state for the United States.

12. Unlike the other impacts, which are expressed in terms of percent change between the baseline and the scenario for the year 2023, the impacts on GHG emissions are for the annual percent changes between the baseline and the scenario averaged over the projection period 2011-2023.

13. In the model, we implement the reduction of 50 million acres. After the model is run and equilibrium is reached, the net result is a 40-million-acre reduction as area responds to increases in prices and returns.

\section{Conflict of Interests}

There is no conflict of interests with any modeling system included in this paper.

\section{Acknowledgment}

This work has also benefited from research funded by the United States Department of Agricultures National Institute of Food and Agriculture/Agriculture and Food Research Initiative, Award number IOW05307.

\section{References}

[1] P. C. Westhoff, The Economics of Food: How Feeding and Fueling the Planet Affects Food Prices, Pearson Education, Upper Saddle River, NJ, USA, 2010.

[2] B. A. Babcock, "The impact of US biofuel policies on agricultural price levels and volatility," Tech. Rep. 35, International Centre for Trade and Sustainable Development, 2011.

[3] U.S. Department of Agriculture (USDA), "The impacts of the American clean energy and security act of 2009 on U.S. agriculture," Office of the Chief Economist, ERSUSDA, December 2009, http://www.usda.gov/oce/newsroom/ archives/releases/2009files/ImpactsofHR2454.pdf.

[4] U.S. Department of Agriculture (USDA), "EU-27. Biofuels Annual," 2010, http://gain.fas.usda.gov/Recent\%20GAIN\% 20Publications/General\%20Report_The\%20Hague_Netherlands-Germany\%20EU-27_6-15-2009.pdf.

[5] T. Searchinger, R. Heimlich, R. A. Houghton et al., "Use of U.S. croplands for biofuels increases greenhouse gases through emissions from land-use change," Science, vol. 319, no. 5867, pp. 1238-1240, 2008.

[6] J. Fargione, J. Hill, D. Tilman, S. Polasky, and P. Hawthorne, "Land clearing and the biofuel carbon debt," Science, vol. 319, no. 5867, pp. 1235-1238, 2008.

[7] T. W. Hertel, A. A. Golub, A. D. Jones, M. O’Hare, R. J. Plevin, and D. M. Kammen, "Effects of US Maize ethanol on global land use and greenhouse gas emissions: estimating market-mediated responses," BioScience, vol. 60, no. 3, pp. 223-231, 2010.

[8] J. Dumortier, D. J. Hayes, M. Carriquiry et al., "Sensitivity of carbon emission estimates from indirect land-use change," Applied Economic Perspectives and Policy, vol. 33, no. 3, pp. 428448, 2011.

[9] California Air Resources Board (CARB), "Initial statement of reasons: proposed regulation to implement the low carbon fuel standard," Staff Report: Volume 1, California Environmental Protection Agency Air Resources Board, Sacramento, Calif, USA, 2009.

[10] J. E. Fargione, R. J. Plevin, and J. D. Hill, "The ecological impact of biofuels," Annual Review of Ecology, Evolution, and Systematics, vol. 41, pp. 351-377, 2010. 
[11] L. E. Revell, G. E. Bodeker, P. E. Huck, and B. E. Williamson, "Impacts of the production and consumption of biofuels on stratospheric ozone," Geophysical Research Letters, vol. 39, no. 10, Article ID L10804, 2012.

[12] J. Dumortier, D. J. Hayes, M. Carriquiry et al., “The effects of potential changes in United States beef production on global grazing systems and greenhouse gas emissions," Environmental Research Letters, vol. 7, no. 2, Article ID 024023, 2012.

[13] A. Elobeid and S. Tokgoz, "Removing distortions in the U.S. ethanol market: what does it imply for the United States and Brazil?" American Journal of Agricultural Economics, vol. 90, no. 4, pp. 918-932, 2008.

[14] F. Rosas, "The worlds fertilizer model-world NPK model," Tech. Rep. 11-WP 520, Center for Agricultural and Rural Development, Iowa State University, 2011.

[15] J. Dumortier, "The effects of uncertainty under a cap-and-trade policy on afforestation in the United States," Environmental Research Letters, vol. 8, no. 4, Article ID 044020, 11 pages, 2013.

[16] B. A. Babcock, "The effects of uncertainty on optimal Nitrogen applications," Review of Agricultural Economics, vol. 14, pp. 271280, 1992.

[17] G. Sheriff, "Efficient waste? Why farmers over-apply nutrients and the implications for policy design," Review of Agricultural Economics, vol. 27, no. 4, pp. 542-557, 2005.

[18] U.S. Department of Agriculture, Economic Research Service (USDA-ERS), "Fertilizer Use and Price," Washington, DC, USA, 2013, http://www.ers.usda.gov/data-products/fertilizeruse-and-price.aspx\#.Um9dEEoq4lp.

[19] World Bank, World DataBank, Global Economic Monitor Commodities, 2012, http://databank.worldbank.org/data/ home.aspx. 

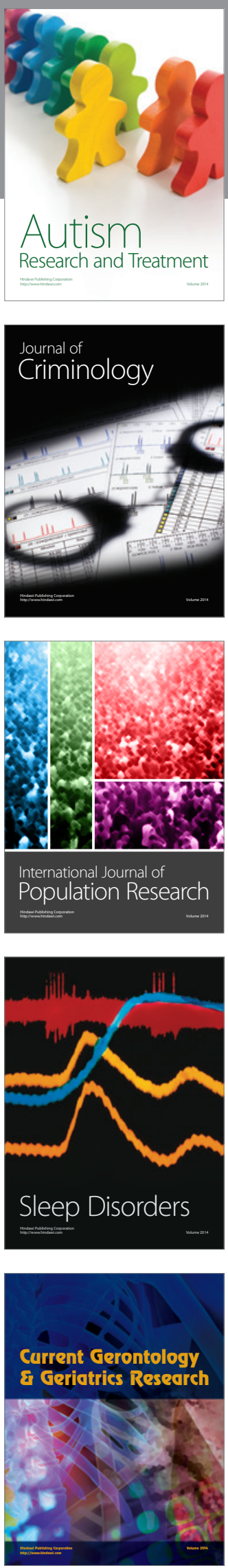
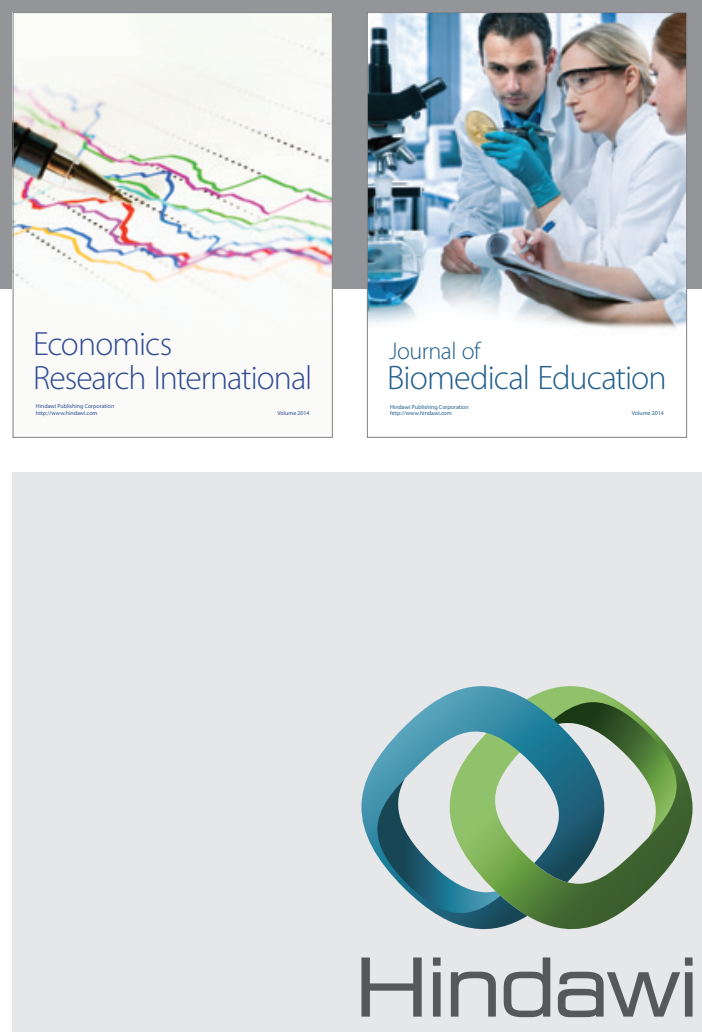

Submit your manuscripts at

http://www.hindawi.com
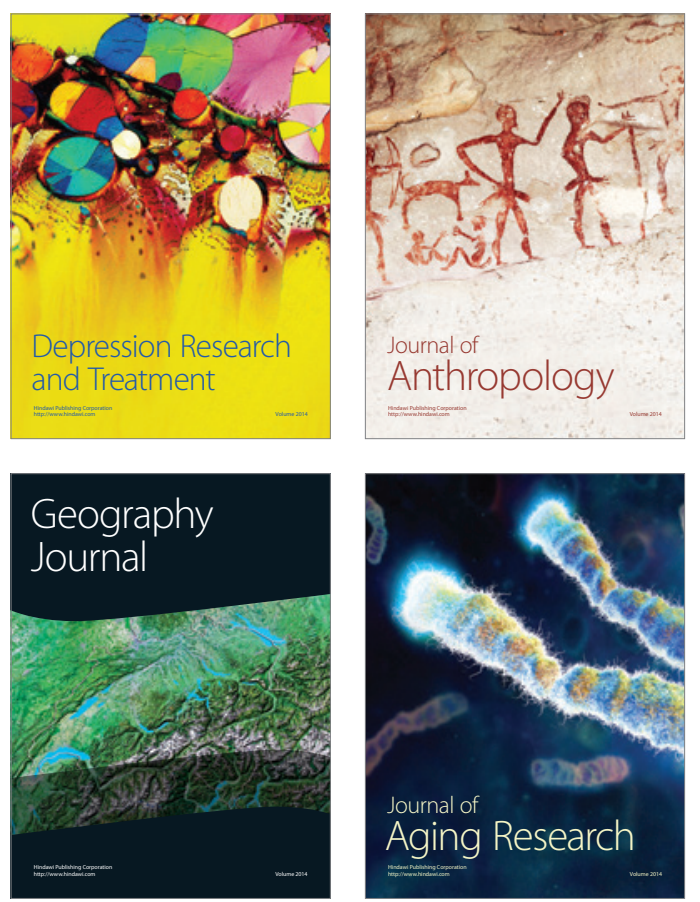
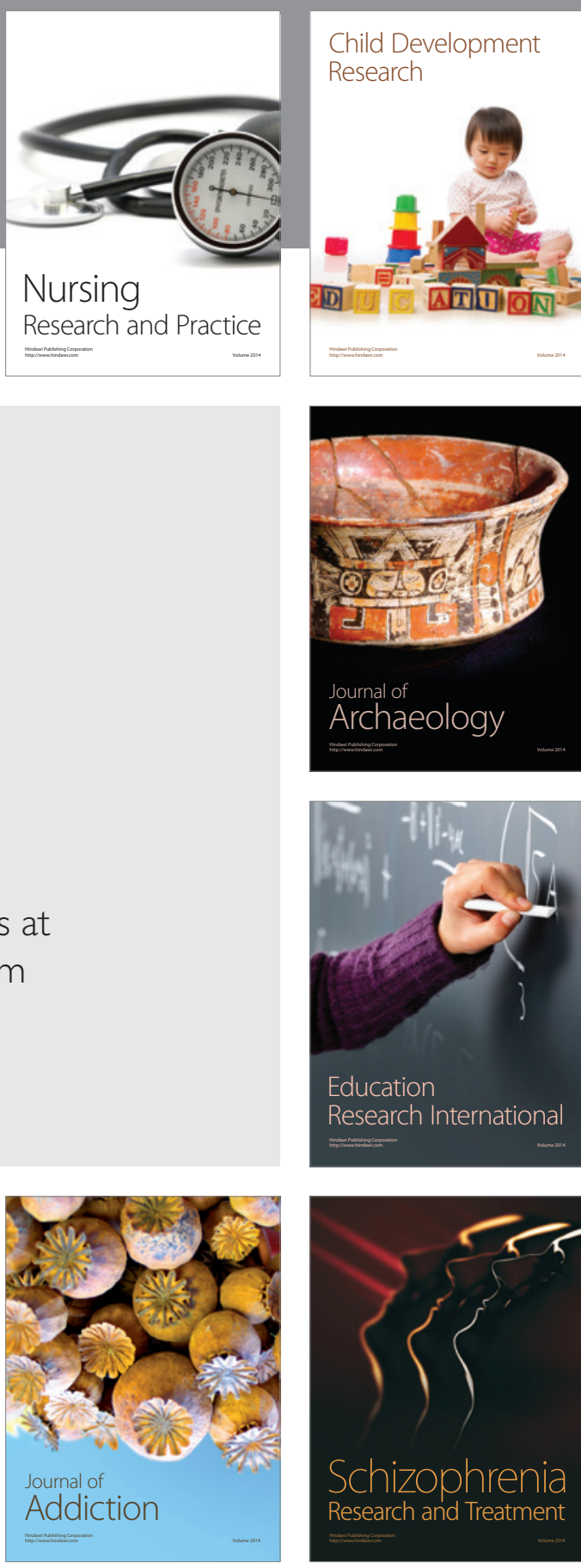

(D)
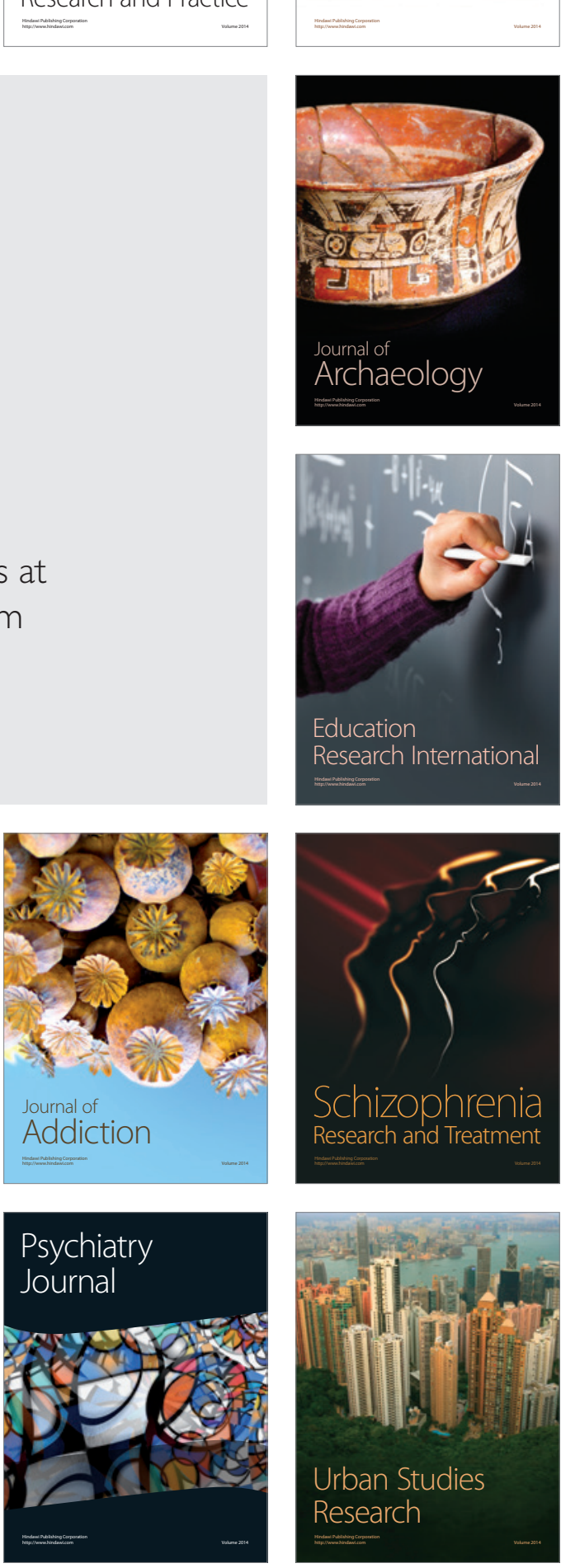